for diagnosis differ from those of disseminated intravascular coagulation in that it is unnecessary to obtain evidence of massive consumption coagulopathy in the form of hypofibrinogenaemia, but sensitive procedures to detect activation of the coagulation mechanism, such as tests for increased fibrin degradation products, are usually positive. In four out of five cases in which the level of fibrin degradation products was recorded it was, in fact, increased. The platelet count is often subnormal, as in cases 1 , 4, 5, and 6 (table I), and fragmented red cells are invariably present, accompanied by a variable degree of haemolytic anaemia and renal failure. (Though platelet count and red cell fragmentation were not documented in case 2 the patient has been included because he had anaemia with a positive Schumm's test, a high blood urea, and a poor urinary output.) Fibrinogen levels may actually be raised in the haemolyticuraemic syndrome (Gilchrist et al., 1969), as was found in case 1. Increased plasma fibrinogen levels in cases of typhoid fever were recorded by Ogston et al. (1964).

Apart from diagnostic considerations the concept of localized intravascular coagulation may also have therapeutic implications. If the role of heparin is accepted it appears rational to infer that localized intravascular coagulation would be controlled by lower doses of heparin than are required for disseminated intravascular coagulation. The outcome was certainly satisfactory in the three cases in our series in which this low dosage scheme was used.

We have been unable to account for the high incidence of the haemolytic-uraemic syndrome in our cases of typhoid as compared with the published experience of others. G-6-PD deficiency was not detected in the four patients in whom it was sought. Except for case 2 the haemolysis and renal failure occurred before treatment with chloramphenicol was started, and this drug can therefore be excluded as the causal agent in these five cases. We found no positive evidence to implicate the traditional herbal remedies as a precipitating factor.

Attention has been drawn to the absence of leucopenia in our cases. A neutrophil leucocytosis in typhoid suggests a complication and could well be another pointer to the development of the haemolytic-uraemic syndrome in this infec- tion. Furthermore, typhoid must be suspected in any case of acute renal failure seen in this region, even if the patient is apyrexial, as were two of ours.

We should like to thank the Secretary for Health, Rhodesia, for permission to submit this paper.

\section{References}

Allen, N. (1969). Fournal of the American Medical Association, 208, 689.

Bernstock, L., and Hirson, C. (1960). Lancet, 1, 28.

Brain, M. C. (1968). Lancet, 2, 1394.

Brain, M. C. (1969). New England fournal of Medicine, 281, 833.

Brain, M. C., Dacie, J. V., and Hourihane, D. O. (1962). British fournal of

Haematology, 8, 358 .
Bull, B. S., Rustenburg, M. L., Dacie, J. V., and Brain, M. C. (1968). British' Fournal of Haematology, 14, 643.

Burmester, H. B. C., Aulton, K., and Horsefield, G. I. (1970). fournal of Clinical Pathology, 23, 43.

Cruikshank, R. (1965). In Medical Microbiology, 11 th edn., p. 907. Edinburgh, Livingstone.

Dacie, J. V., and Lewis, S. M. (1968). In Practical Haematology, 4th edn. London, Churchill.

Faierman, D., Ross, F. A., and Seckler, S. G. (1972). fournal of the American Medical Association, 221, 60.

Gervais, M., Richardson, J. B., Chiu, J., and Drummond, K. N. (1971).

Pediatrics, 47,352 .
Gilchrist, G. S., Lieberman, E., Ekert, H., Fine, R. N., and Grushkin, G. (1969). Lancet, 1, 1123 .

Gulati, P. D., Saxena, S. N., Gupta, P. S., and Chuttani, H. R. (1968). American fournal of Medicine, 45, 544.

Hardisty, R. M., and Ingram, G. I. C. (1965). In Bleeding Disorders, Investigation and Management, p. 138. Oxford, Blackwell Scientific.

Hersko, C., and Vardy, P. A. (1967). British Medical fournal, 1, 214.

Huckstep, R. L. (1962). Typhoid Fever and other Salmonella Infections, p. 180.

Edinburgh, Livingstone.
Kaufman, F. (1965). In The Bacteriology of Enterobacteriaceae, p. 170. Baltimore, Williams and Wilkins.

La Grutta, A., Balsamo, V., and Mollica, F. (1967). British Medical fournal, 2,175 .

Lwanga, D., and Wing, A. J. (1970). East African Medical fournal, 47, 146. McCaffrey, R. P., Halsted, C. H., Wahab, M. F. A., and Robertson, P. P. (1971). Annals of Internal Medicine, 74, 722.

Merskey, C., Kleiner, G. J., and Johnson, A. J. (1966). Blood, 28, 1.

Ogston, D., Edward, N., and McAndrew, G. M. (1964). Scottish Medical fournal, 9, 399.

Retief, F. P., and Hofmeyr, N. G. (1965). South African Medical fournal,

$39,96$.
Wicks, A. C. B., Holmes, G. S., and Davidson, L. (1971). Quarterly fournal of Medicine, 40, 341 .

Wootton, I. D. P. (1964). In Microanalysis in Medical Biochemistry, 4th edn., p. 79. London, Churchill.

\title{
Renal Tubular Obstruction by Mucoproteins from Adenocarcinoma of Pancreas
}

\author{
J. R. HOBBS， D. J. EVANS， O. M. WRONG
}

British Medical fournal, 1974, 2, 87-89

\section{Summary}

We report a case in which mucoproteins from an adenocarcinoma of the pancreas, released into the ascitic fluid and serum, were filtered through the renal glomeruli to form very viscous casts which obstructed the renal collecting tubules and caused the patient's death from oliguria.

\footnotetext{
Tumour Biology Group, Westminster Hospital Medical School, London S.W.1

J. R. HOBBS, M.D., F.R.C.P., Professor of Chemical Pathology

Royal Postgraduate Medical School, London W12 OHS

D. J. EVANS, M.в., B.CH., Senior Lecturer in Pathology

University College Hospital, London WC1E 6AU

O. M. WRONG, M.D., F.R.C.P., Professor of Medicine
}

\section{Introduction}

Obstruction of the renal collecting tubules with protein casts occurs in up to $30 \%$ of patients with myelomatosis (Heptinstall, 1966). It is most often associated with Bence-Jones proteinuria, but occasionally with other proteinuria-for example, IgA (Hobbs, 1966). Oliguric renal failure sometimes occurs with prominent tubular casts in nephrotic patients with heavy albuminuria (Chamberlain et al., 1966). We report a patient who died because his renal tubules were obstructed by the mucoproteins from an adenocarcinoma of the pancreas.

\section{Case Report}

The patient was a civil servant aged 43 years. In mid-April 1967 he developed nausea, vomiting, and abdominal pain. On 27 April he was admitted to a local hospital as an emergency. No abnormalities were found on physical or barium meal examination, the blood urea was $32 \mathrm{mg} / 100 \mathrm{ml}$, and haemoglobin $14 \mathrm{~g} / 100 \mathrm{ml}$. His urine contained protein. The symptoms subsided on a milk diet and he 
was discharged, but on 19 May he was readmitted with vomiting, nausea, and constipation. His blood urea was then $340 \mathrm{mg} / 100 \mathrm{ml}$ and haemoglobin $11 \mathrm{~g} / 100 \mathrm{ml}$. His urine was scanty (under $200 \mathrm{ml} /$ day) and contained abundant protein. Because of a rising blood urea he was transferred to Hammersmith Hospital on 22 May. The only physical abnormalities found were a uraemic foetor and a fullness on the right side of the pelvis on rectal examination; his urine contained red cells and abundant protein. Investigations were: blood pressure, $135 / 90 \mathrm{~mm} \mathrm{Hg}$; blood urea, $450 \mathrm{mg} / 100 \mathrm{ml}$; plasma sodium, $131 \mathrm{mEq} / 1$; potassium, $5.6 \mathrm{mEq} / 1$.; chloride, 81 $\mathrm{mEq} / 1$; bicarbonate, $20 \mathrm{mEq} / 1$; caloium, $5.0 \mathrm{mEq} / 1$; phosphate, $4.2 \mathrm{mEq} / 1$; serum bilirubin, $0.4 \mathrm{mg} / 100 \mathrm{ml}$; alkaline phosphatase, $6 \mathrm{~K} . \mathrm{A}$. units; isocitric dehydrogenase, $11 \mathrm{IU}$; lactric dehydrogenase, $165 \mathrm{IU}$; cholesterol, $195 \mathrm{mg} / 100 \mathrm{ml}$; amylase, 230 Somogyi units/ $100 \mathrm{ml}$; haemoglobin, $11.4 \mathrm{~g} / 100 \mathrm{ml}$; W.B.C., $11,000 / \mathrm{mm}^{3}$ with normal differential; E.S.R. $78 \mathrm{~mm} / \mathrm{hr}$ (Westergren). An $x$-ray examination of the abdomen showed kidneys $15 \mathrm{~cm}$ in long axis.

Peritoneal dialysis was begun immediately. Several hundred $\mathrm{ml}$ of straw-coloured ascitic fluid were removed and histological examination showed clumps of mucus-secreting adenocaroinoma cells. A mobile mass then became palpable in the right iliac fossa. With continuous peritoneal dialysis the blood urea was maintained at below $100 \mathrm{mg} / 100 \mathrm{ml}$, but vomiting persisted and urine output never rose above $50 \mathrm{ml} /$ day. Retrograde pyelography on 27 May showed a normal collecting system on both sides. A right renal biopsy specimen taken on 1 June showed massive cast formation in distal convoluted and collecting tubules (fig. 1); many of the casts appeared cracked and were associated with syncytial multinucleate giant cells. There was moderate interstital fibrosis and lymphocyte infiltration. The changes were characteristic of those seen in myelomatosis. On 6 June the patient developed superficial thrombophlebitis above both ankles and over the next two weeks this extended widely, involving both thighs.

Laparotomy on 12 June showed that the peritoneum was studded with malignant nodules; histological examination showed welldifferentiated adenocarcinoma (fig. 2). In view of the disseminated nature of the tumour and the usual resistance of such tumours to therapy no further treatment was given. The patient died on 28 June with considerable ascites, a blood urea of $400 \mathrm{mg} / 100 \mathrm{ml}$, and serum potassium of $10.2 \mathrm{mEq} / 1$.

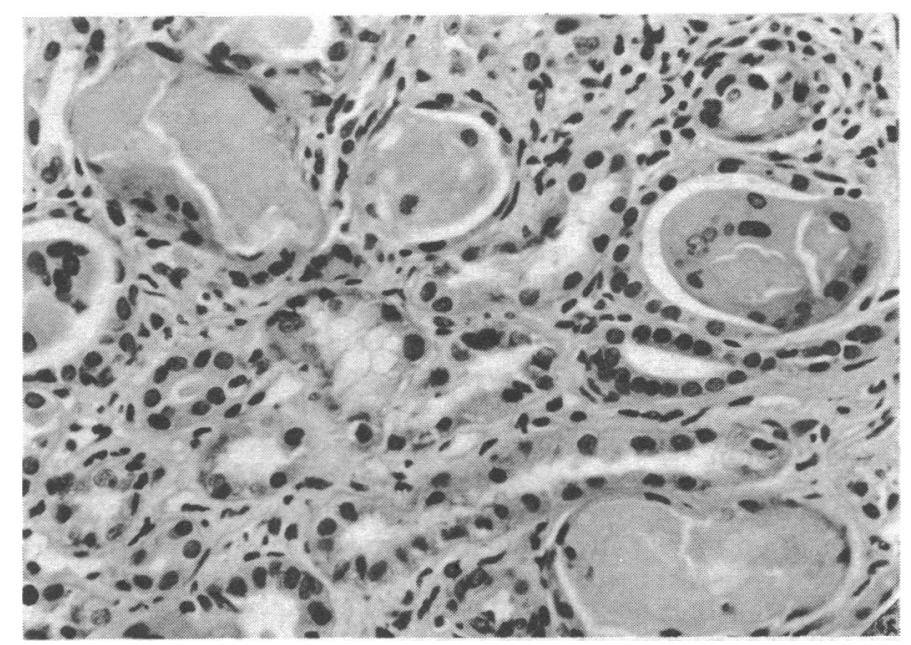

FIG. 1-Renal biopsy showing tubules distended by casts which are exciting a giant-cell response. (Haematoxylin and cosin. $\times 288$.)

\section{HISTOPATHOLOGY}

At necropsy the kidneys were of normal size and had features essentially similar to those of the renal biopsy specimen (fig. 1). The glomeruli were within normal limits. The epithelium of the proximal tubules was flattened and there was interstital fibrosis with a moderate, patchy, inflammatory infiltrate of polymorphs, eosinophils, and lymphocytes. Many of the distal convoluted and colleoting tubules were disterded by casts which appeared eosinophilic and of "hard" ourline. These casts were sometimes lami-

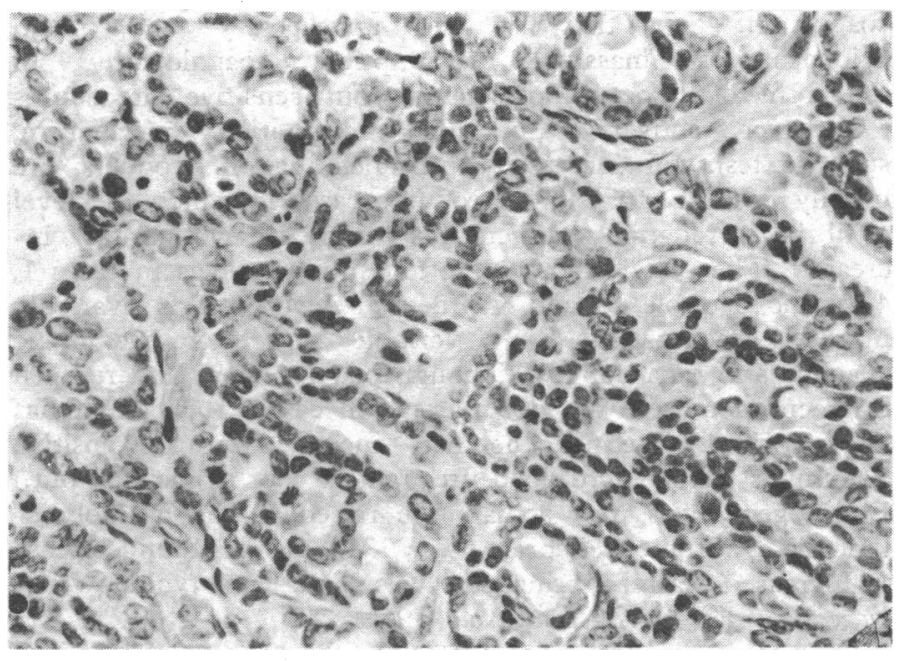

FIG. 2-Biopsy of metastasis from pancreatic tumour showing ducts which contain mucin. (Haematoxylin and eosin. $X$ 288.)

nated and sometimes cracked and, especially in the distal tubules, had excited a giant-cell reaction. They were strongly positive with the periodic acid-Schiff stain but Alcian blue gave no reaction. Granular casts were not seen in the kidney. Microscopic appearances closely resembled those of a "myeloma kidney." Careful examination of the vertebrae, femur, and sternum failed to find any tumour. The pancreatic body and tail were replaced by a mass of primary carcinoma. The local lymph nodes were also enlarged up to $2.5 \mathrm{~cm}$ diameter and replaced by tumour, and there were plaques and nodules of tumour present on the diaphragm, mesentery, omentum, and parietal peritoneum. No extra-abdominal spread was found. Microscopically the tumour was a carcinoma showing considerable nuclear pleomorphism and a high mitotic rate, but well-formed ducts were present (fig. 2). Mucin stains (prriodic acidSchiff, Alcian blue) were positive, and no zymogen granules were seen on sections stained with phosphotungstic acid haematoxylin. The carcinoma was thought to be of ductal rather than of acinar origin. There was superficial venous thrombosis in the arms and legs. The heart showed no evidence of thrombotic endocarditis.

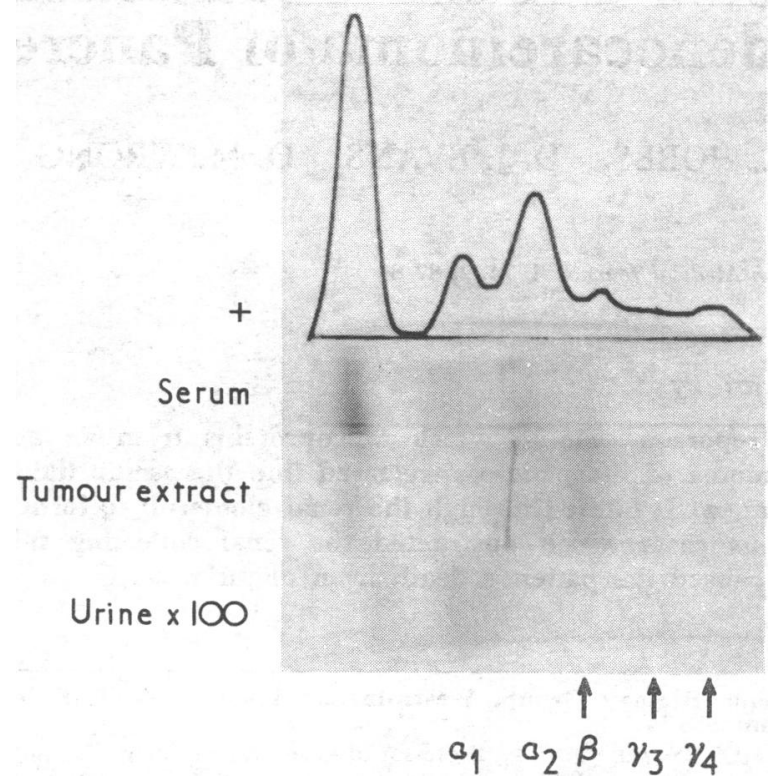

FIG. 3-Electrophoresis of tumour extract and urine concentrate alongside patient's serum. Serum shows a noticeably raised $\alpha_{1}$-and $\alpha_{2}$-globulins, which like excess $\alpha_{1}-$ globulin in urine are frequent in patients with carcinomatosis. There is no abnormality seen in in $\gamma$-globulins. Tumour extract and urine show three unique bands in $\beta, \gamma_{2}, \gamma_{1}$ positions which were P.A.S. positive and represent pancreatic mucoproteins. 


\section{PROTEIN STUDIES}

No evidence of myelomatosis could be found-no bony involvement, no abnormal plasma cells, and no abnormalities in the serum immunoglobulins (IgG $710 \mathrm{mg} / 100 \mathrm{ml}$, normal $510-1600$ $\mathrm{mg} / 100 \mathrm{ml}$; IgA $315 \mathrm{mg} / 100 \mathrm{ml}$, normal $125-425 \mathrm{mg} / 100 \mathrm{ml} ; \mathrm{IgM}$ $50 \mathrm{mg} / 100 \mathrm{ml}$, normal $47-170 \mathrm{mg} / 100 \mathrm{ml}$ ), nor were any BenceJones protein or other immunoglobulin fragments shown by immunoelectrophoresis of the urine concentrated 100 times.

The concentrated urine was remarkable in having a noticeably viscous consistency and in showing, after electrophoresis, three unique bands with $B,{ }^{3}$, and $\gamma^{4}$, mobilities (fig. 3). These all stained clearly by a periodic acid-Sohiff method, when identical bands were found in an extract of the tumour and in the ascitic fluid and were even faintly visible in serum stained by P.A.S A rabbit antiserum raised against the urine concentrate of the patient and absorbed with normal urine concentrate reacted only with the patient's fluids, tumour extract, and the occasional cast in the urine deposit. Unfortunately the kidney obtained at necropsy, which had been stored unfixed at $-70^{\circ} \mathrm{C}$ to permit fluorescent antibody studies, was lost by accident.

\section{Discussion}

The oliguric renal failure in this patient resulted from the cast formation obstructing the distal and collecting renal tubules. His carcinoma of the pancreas contained mucoproteins, and from the electrophoretic staining of the ascitic fluid, serum, and urine obviously these were being liberated to enter the circulation. There seems little doubt that it was these mucoproteins which, after filtration through the glomeruli, became concentrated in the collecting tubules with the resultant formation of casts. We do not know whether intrinsic proteins-such as
Tamm-Horsfall-needed in the formation of other renal casts were necessary in this case. Renal failure due to obstruction of the renal tubules by casts has long been recognized in patients with myelomatosis with heavy Bence-Jones proteinuria, the syndrome being called "myeloma-kidney." A similar sequence may contribute to renal failure in some cases of primary nephrotic syndrome, including that caused by minimal glomerular change (Connolly, et al., 1968), where retention of a large filtration surface can result in the heaviest proteinuria.

The syndrome of "myeloma-kidney" can now therefore occur in three known clinical situations (1) with heavy proteinuria, (2) with pancreatic carcinoma, and (3) with paraproteinuria. As the morphological appearances in the kidney in the last two conditions are identical they can no longer be considered pathognomonic of myeloma. The earlier the diagnosis can be made in these situations the more chance there is of affecting the otherwise inevitable outcome, and electrophoretic examination of concentrated urine is an essential investigation. A high fluid throughput of 31 . daily should be maintained and intravenous pyelography avoided, especially when it involves fluiddeprivation. In this way the incidence of renal tubular obstruction in myelomatosis has been kept to less than $10 \%$ in the current Medical Research Council trials.

\section{References}

Chamberlain, M. J., Pringle, A., and Wrong, O. (1966). Quarterly fournal of Medicine, 35, 215.

Connolly, M. E., Wrong, O. M., Jones, N. F. (1968). Lancet, 1, 665.

Heptinstall, R. H. (1966). Pathology of the Kidney, pp. 5 and 7. London, Churchill.

Hobbs, J. R. (1966). The Scientific Basis of Medicine, p. 121. London, Athlone.

\begin{abstract}
Summary
A total of 178 patients with obstructive airways disease were studied between 1966 and 1972, a period which followed a substantial fall in atmospheric pollution in Sheffield. Compared with patients from an earlier study of the same age and smoking habits they had less productive cough, fewer winter illnesses, less severe breathlessness, and only one-third of the rate of decline of forced expiratory volume (FEV). The analysis of the change in the annual loss of FEV was complicated. There were virtually no sudden steep falls of respiratory function, and patients with very low values of FEV survived for long periods. The predominant cause of death was cor pulmonale.

Chronic hypoxia may be more of a problem in the next few years than bronchial infection. I believe that the clean air policy has effected an improvement and that the nature of chronic bronchitis with severe obstructive airways disease is changing, but further studies will be needed to confirm this.
\end{abstract}

Department of Medicine, Sheffield University, Sheffield S1 3SR PETER HOWARD, D.M., M.R.C.P., Senior Lecturer

\section{Introduction}

Chronic bronchitis is defined by the production of sputum. Its incidence varies widely both between different countries and between different communities. At least $25 \%$ and sometimes $50 \%$ of heavy smokers in industrial communities in England were found to produce mucus excessively and were labelled chronic bronchitics (Higgins et al., 1956; Higgins et al., 1959; College of General Practitioners, 1961). The production of sputum, however, attracted less attention than its associated disabling complications-airways obstruction, with severe breathlessness, and pulmonary heart failure, Bronchial infection, cigarette smoking, and atmospheric pollution have been principally accused of causing progressive airways obstruction, though the causative mechanism has never been clearly defined. This paper describes an attempt to elucidate the aetiology of the disease by studying its evolution over a period of time. A prospective study was made of 178 patients with established airways obstruction, and special attention was paid to the progress of the obstruction and to the cause of death The findings were compared with those from a previous group studied six years earlier in the same clinic.

\section{Patients and Methods}

All patients attending the bronchitis clinic in the first three months of 1966 were admitted to the study, which ended on 